\title{
Science Engagement Survey A new tool for primary science
}

\section{SANDY ROBBINS and ROSEMARY HIPKINS}

The science education team at the New Zealand Council for Educational Research (NZCER) has designed two new online student surveys, one for Years $0-4$ and one for Years 5-IO. They have just been loaded onto NZCER's test platform, where they are currently free to try out.

The survey prompts students to think about a wide range of possible learning experiences in science. Students might be asked to say how interested they are in a particular context or experience, and to say whether they have had opportunities to do this sort of thing at school. The survey for younger children includes images to give them a clear idea of the sorts of experiences being described. Teachers can read the words, if necessary, so literacy is not a barrier to participation. Results for a class are collated as students respond. Teachers do not see individual responses, but they do get a whole class report.
An example of an item from the junior survey is shown in Figure I.

\section{Why focus on engagement?}

Lately, policy-makers have shown a renewed interest in science learning at school. For example the Ministry of Business, Innovation and Employment recently released a national strategic plan called $A$ Nation of Curious Minds (Ministry of Business, Innovation and Employment, 20I4). The plan argues that science and technology are critical for enhancing living standards through economic growth and improving social and environmental outcomes. Making sure more of our young people are competent in science and technology and want to go on to a career in science, technology, engineering, and

Hannah is 6 years old. She has drawn what she thinks is inside her body. Josh is 7 years old. He has drawn how he thinks a shadow is made.

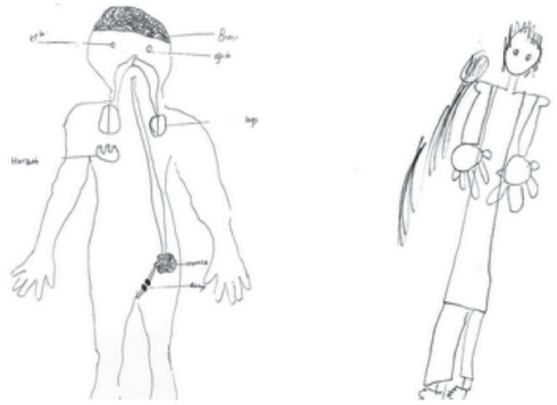

In class do you draw pictures about what you think? 
mathematics (STEM)-related jobs is one of the three specific goals the report identifies.

All this policy attention has given a boost to professional learning opportunities in primary science. We have become aware that some schools now want to see the "value add" for this professional learning. School leaders and advisers who work with them are asking for ways to measure achievement in science. This isn't surprising given the current emphasis on data-driven decision making in literacy and numeracy. But we simply don't know enough (yet) about what making progress in primary science might look like. We don't have the equivalent of PAT or asTTle tools to be able to readily gather meaningful achievement data.

This tool will give schools rich information about their students' engagement with science and their perceptions of the learning opportunities that have been provided for them. In this way, it provides a useful starting point for designing a science programme that is responsive to students' interests and needs, and that more deliberately broadens their "library of experiences" related to science ideas and events (see Bull, 20II).

\section{Accessing the survey}

If your school is already subscribed to NZCER Marking, it is very straightforward to access the Science Engagement Survey. Simply log in and create a science engagement survey in the same way as you would use any other NZCER assessment tool. You will need to click on the "Activate Access" button to get started.

If your school has not yet subscribed to the marking service you will need to create an account:

- Type www.nzcermarking.org.nz into your web browser, click on the "Subscribe" button and complete the registration form, making sure you select Science Engagement Survey. You will notice there is no charge when you select the survey. You will receive an email with your administrator username and password.

- You will then be able to create your own class survey when you log in. Click on "Add new assessment" and enter a class name, the term, and the year level of your students, then click "Add". (You will need to create a separate assessment for each year level in your class.)

- Go back to the Science Survey page and in the "assessments" you have created you will find the class token which is the password each class member will need to access the survey. Students can then type in the survey URL (http://www.nzceronline.org.nz/) and the class token for their class.

- When they have done the survey and you want to see the report click on the "Reports" tab on the top black tool bar and the "Item Report" icon for the class you wish to view.

\section{Why the tool is free to use for the meantime}

We are curious about the sorts of science-learning experiences that are common and not-so-common in primary schools. As different schools access and use the survey we hope to build a much clearer picture about what is happening, and where the gaps are. No other school will see your data, but we will add it to our growing national profile. At some point we will want to write about what we are finding. It is a gift from NZCER to you, but there is also something in it for us!

Norming trials, such as those that are used when PATs are being built or updated, cost a lot of money. This time we are doing things the other way around and building the national profile as we go. Later, when a critical mass of data has accumulated, we will explore options to generate different report formats that enrich the feedback the tool can provide. At that point, we may begin to charge for its use. But that decision lies well in the future. In the meantime, please do try it out and let us know how useful you find it.

\section{References}

Bull, A. (201I). Library of experiences. [Working paper]. Retrieved from http://www.nzcer.org.nz/research/ publications/library-experiences

Ministry of Business, Innovation and Employment. (2014). A nation of curious minds - He whenua hihiri i te mahara: A national strategic plan for science in society. Retrieved from http://www.msi.govt.nz/assets/MSI/Update-me/Science-insociety-project/science-in-society-plan.pdf

Sandy Robbins is a support and data analyst at the New Zealand Council for Educational Research

Email: Sandy.Robbins@nzcer.org.nz

Rosemary Hipkins is a chief researcher at the New Zealand Council for Educational Research.

Email: Rosemary.Hipkins@nzcer.org.nz 